\title{
Analysis of Wien Bridge Oscillator Designed Using BJT and Memristor with Different Window Functions
}

\author{
İshak Parlar $^{1 *}$, Mehmet Nuri Almal1 $^{1}$, Ali Can Çabuker ${ }^{1}$ \\ 1* Van Yuzuncu Yil University, Faculty of Engineering, Departmant of Electrical and Electronics Engineering, Van, Turkey, (ORCID: 0000-0002-3383-8091), \\ ishakparlar@yyu.edu.tr \\ ${ }^{2}$ Van Yuzuncu Yil University, Faculty of Engineering, Departmant of Electrical and Electronics Engineering, Van, Turkey, (ORCID: 0000-0003-2763-4452), \\ mna1@yyu.edu.tr \\ ${ }^{3}$ Van Yuzuncu Yil University, Faculty of Engineering, Departmant of Electrical and Electronics Engineering, Van, Turkey, (ORCID: 0000-0003-2011-2117), \\ alicancabuker@gmail.com
}

(1st International Conference on Applied Engineering and Natural Sciences ICAENS 2021, November 1-3, 2021)

(DOI: 10.31590/ejosat.993302)

ATIF/REFERENCE: Parlar, İ., Almalı, M.N., Çabuker, A.C. (2021). Analysis of Wien Bridge Oscillator Designed Using BJT and Memristor with Different Window Functions. European Journal of Science and Technology, (28), 140-143.

\begin{abstract}
In this document, first of all, code sections of memristor window functions (Strukov, Joglekar, Biolek and Prodromakis) were created in Pspice package program in detail. Then, the design of the wien bridge oscillator circuit with BJT with a memristor with different window functions was created. Finally, the system's oscillation start time, oscillation band settling time and center oscillation frequency analysis data were imported into the Matlab program and a comprehensive presentation was made. It was seen that the output responses of the wien bridge oscillator circuit realized with the Strukov window function were better than the other window functions. It has also been shown that designs that can be realized with memristor with different window functions in various analog oscillator circuits that can be made in the future can be obtained with this method.
\end{abstract}

Keywords: Window functions, Wien bridge oscillator, Memristor, Center oscillation frequency, Pspice.

\section{Farklı Pencere Fonksiyonları ile BJT ve Memristor Kullanılarak Tasarlanan Wien Bridge Osilatörünün Analizi}

Öz

Bu dokümanda öncelikle memristor pencere fonksiyonlarının (Strukov, Joglekar, Biolek ve Prodromakis) kod bölümleri Pspice paket programında detaylı olarak oluşturulmuştur. Daha sonra farklı pencere fonksiyonlarına sahip memristör kullanarak BJT'li wien köprü osilatör devresinin tasarımı oluşturulmuştur. Son olarak sistemin osilasyona başlama zamanı, osilasyona oturma zamanı ve merkez osilasyon frekansı analiz verileri Matlab programına aktarılarak kapsamlı bir sunum yapılmıştır. Strukov pencere fonksiyonu ile gerçekleştirilen wien köprü osilatör devresinin çıkış tepkilerinin diğer pencere fonksiyonlarına göre daha iyi olduğu görülmüştür. Ayrıca gelecekte yapılabilecek çeşitli analog osilatör devrelerinde farklı pencere fonksiyonlarına sahip memristör ile gerçekleştirilebilecek tasarımların bu yöntemle elde edilebileceği de gösterilmiştir.

Anahtar Kelimeler: Pencere fonksiyonları, Wien köprü osilatörü, Memristor, Osilasyon merkez frekansı, Pspice.

\footnotetext{
* Corresponding Author: ishakparlar@yyu.edu.tr
} 


\section{Introduction}

This study gives important clues about how to use and implement memristor with different window functions in analog circuits. To date, many different window functions have been proposed and continue to be proposed (Strukov et al., 2008; Joglekar and Wolf, 2009; Biolek et al., 2009; Prodromakis et al., 2011; Kvatinsky et al., 2012; Yu et al., 2013). Among them, Strukov, Biolek, Joglekar and Prodromakis, which can be considered the most important, are the most preferred. Each of them creates structures suitable for use in different analog circuits. Especially in analog circuits that require precision, the usage areas are increasing day by day.

Wien bridge oscillator circuit, which is one of the RC oscillators, is one of the most preferred signal generators. Other signals can be derived from this circuit. Generating signals with the desired amplitude and frequency also necessitates sensitivity. At this point, memristor window functions come into play. As with many other methods, this method can be considered relatively easy to use, perform and apply. In this study, the wien bridge oscillator circuit with BJT was created by moving away from the traditional structure. Series and parallel R-C elements were created with M-C. The rest of the structure was preserved as it was. At the output of the circuit, the oscillation start time, the oscillation band settling time and the center frequency were calculated in detail, and the reliability of the system was verified with the results. It was seen that the Strukov window function was faster and more robust than the other window functions. In the following sections, system design, code part and results will be discussed.

\section{Material and Method}

Different window functions were created one by one with the Pspice code shown in Figure 1. The initial states are exactly the same, but the only difference is the algebraic expressions of the functions we use.

\subsection{Window Functions}

Window function is state variable function. The window function pushes the element's boundaries and helps it exhibit non-linear behaviour near these boundaries. Many window functions have been proposed so far. These window functions were simulated in the SPICE model, and the differences in current and voltage were observed. The window functions applied are mainly: Strukov, Biolek, Joglekar and Prodromakis.

If we consider each window function one by one mathematically; Strukov window function (Strukov et al., 2008)

$$
f(\mathrm{x})=\mathrm{x}-\mathrm{x}^{2}
$$

This window function lacked flexibility. Later, another window function was proposed by Joglekar. The system could be controlled with a positive integer $p$ (Joglekar and Wolf, 2009; Rak and Cserey, 2010; Chua, 2010).

$$
f(\mathrm{x})=1-(2 \mathrm{x}-1)^{2 p}
$$

An important problem of this model is based on the fact that if $\mathrm{W}$ (the physical length of the memristor) is at any limit ( $w=0$ or $w=D$ ), the device cannot be reset to its original position after reaching the endpoints. At this point, we encounter the Biolek memristor back from the terminal state problem until you suggest another window function that lets it come through (Biolek et al., 2009).

$$
f(\mathrm{x})=1-(\mathrm{x}-\operatorname{stp}(-\mathrm{i}))^{2 p}
$$

The newest window function was finally suggested by Prodromakis [4].

$$
f(\mathrm{x})=1-\left[(\mathrm{x}-0.5)^{2}+0.75\right]^{p}
$$

Boundary issues are resolved with the window function that returns zero on active double-layer edges.

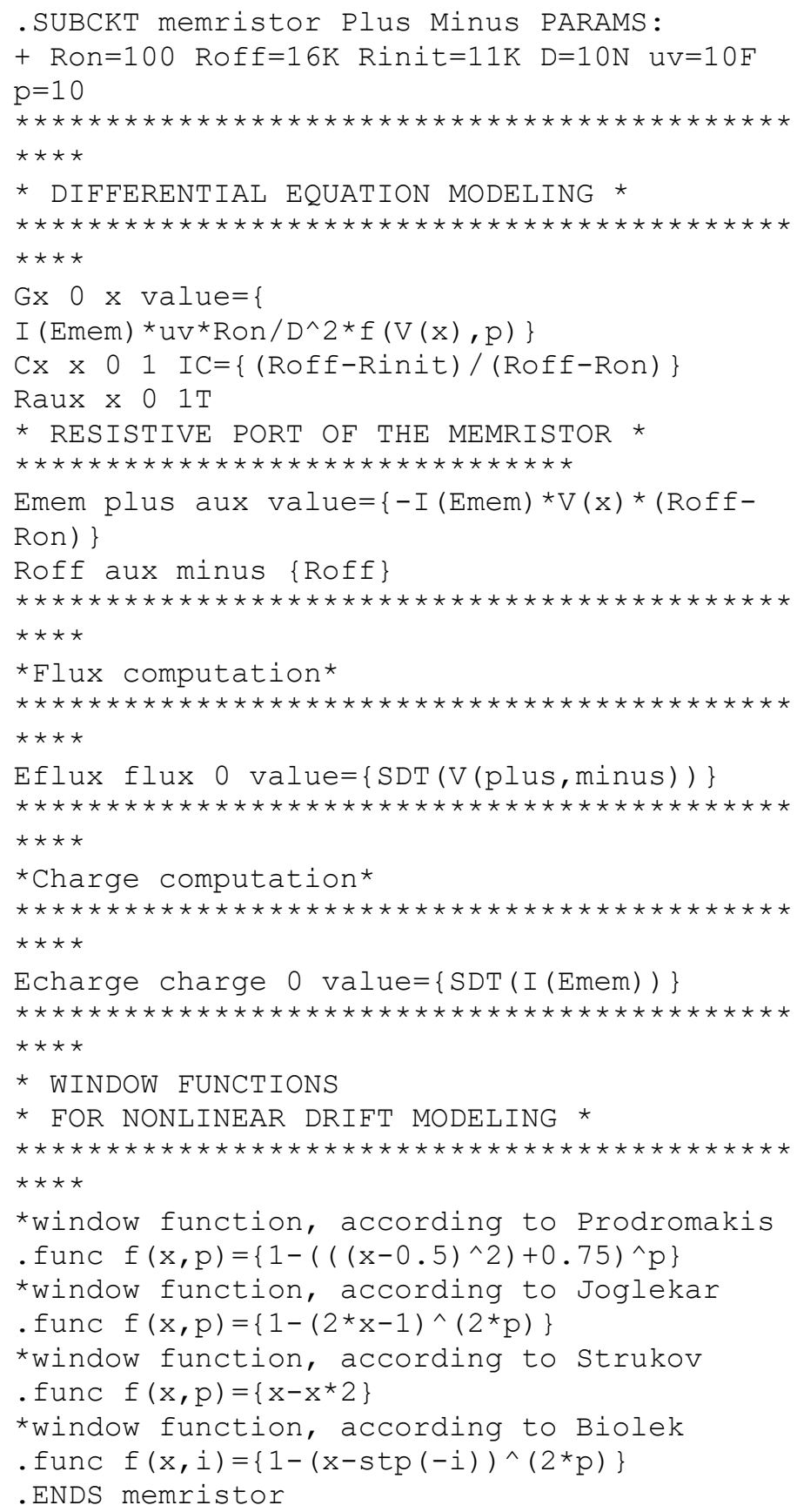

Figure 1. Memristor Pspice Window Function Code (Strukov et al., 2008) 
Memristor parameter values; $u v, D, \quad R_{O N}, R_{O F F}$ and $R_{\text {INITIAL }}$ are defined as $10^{-10} \mathrm{~cm}^{2} \mathrm{~s}^{-1} \mathrm{~V}^{-1}, 10 \mathrm{~nm}, 100 \Omega, 16 K \Omega$ and $11 K \Omega$, respectively. Window function is defined as $p=10$ for all models (Strukov et al., 2008; Joglekar and Wolf, 2009; Biolek et al., 2009).

\subsection{Proposed Wien Bridge Oscillator}

Since the traditional wien bridge oscillator structure, which is one of the RC oscillators, is preferred in the literature, the serial and parallel RC structures, which are the main structure, were preserved by using the double BJT structure instead of this structure (Martínez-García, 2013; Namajunas and Tamasevicius,1995). Wien bridge oscillator structure with Memristor is shown in Figure 2. In this structure, resistors in both series and parallel parts have been replaced by memristor, which displays different window functions.

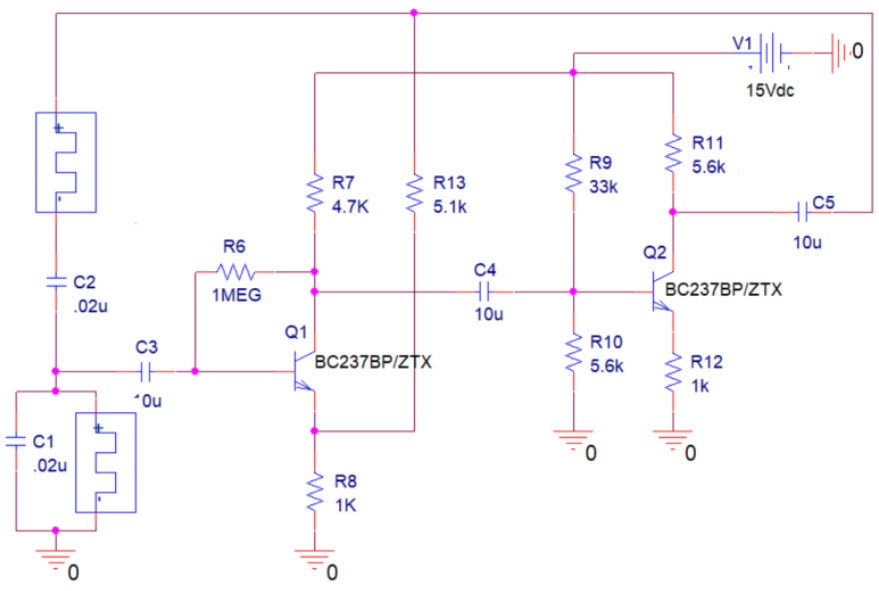

Figure 2. Wien Bridge Oscillator Circuit Designed with Memristor

In this structure, the gain of the system can be controlled by compensating the second BJT part from the first part with a capacitor. Outputs from the collector of each BJT create a phase difference of 180 degrees and move the output voltage to a positive point. The general center frequency of this system can be calculated with $1 /\left(2 \pi\left(R_{\text {INITIAL }} \approx M\right) C\right)$. Here, the center oscillation frequency of the system can be changed by adjusting the $R_{\text {INITIAL }} \approx M$ value. In this study, the center oscillation frequency was calculated as approximately $723 \mathrm{~Hz}$.

\section{Results and Discussion}

\subsection{Output Parameter Analysis}

In Figure 3, the settling and oscillating start times of the wien bridge oscillator designed with a memristor with different window functions are shown. When both settling time and oscillation start times are considered, it is clearly seen that the Strukov window function comes to the prominent.

When looking at the frequency spectrum of the proposed wien bridge oscillator circuit in Figure 4, it is calculated that the center oscillation frequency is very close to the theory.

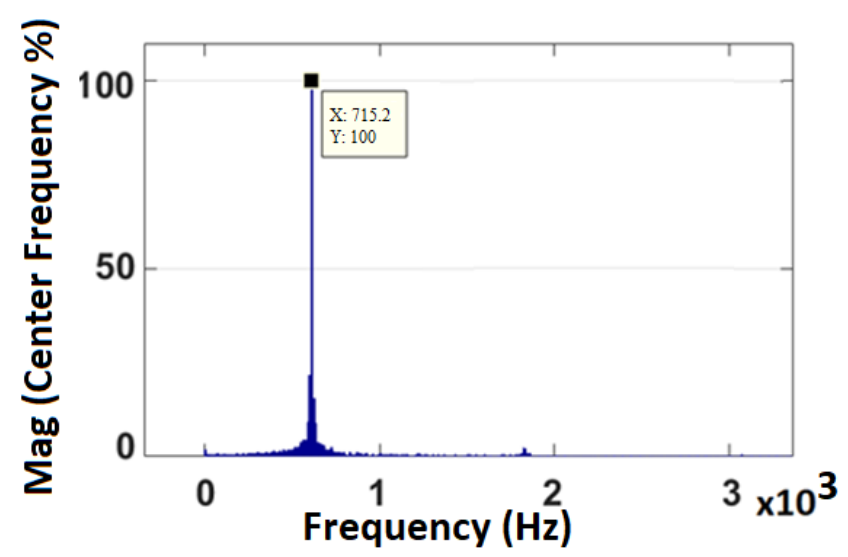

Figure 4. Center Oscillation Frequency of The Strukov Window Function

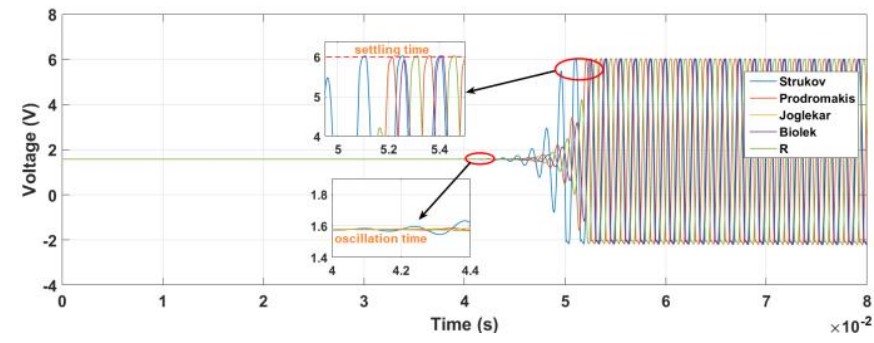

Figure 3. Effects of Different Window Functions on Settling Time for Wien Bridge Oscillator Circuit with Memristo

In the table given below, the settling and oscillation start times of each window functions are given in detail. As can be seen from the table, the superiority of the Strukov model has been observed.

Table 1. Oscillation Start and Settling Times of Different Window Functions on The Proposed Wien Bridge

\begin{tabular}{l|c|c}
\hline Window Functions/ R & $\begin{array}{c}\text { Oscillation } \\
\text { Start } \\
\text { Time (ms) }\end{array}$ & $\begin{array}{c}\text { Oscillation } \\
\text { Settling } \\
\text { Time (ms) }\end{array}$ \\
\hline Strukov & 40.8 & 50.8 \\
\hline Prodromakis & 42.1 & 52.0 \\
\hline Joglekar & 43.2 & 52.6 \\
\hline Biolek & 43.2 & 52.6 \\
\hline R(Resistor) & 43.0 & 53.1 \\
\hline
\end{tabular}

When we look at the literature, it is seen that memristor window functions are generally studied on analog filters. There are also studies on different analog oscillators, but this study can be unique in terms of creating a non-traditional wien bridge oscillator in this way. In addition, comparing with more than one window function increases the efficiency of the study.

\section{Conclusions and Recommendations}

As a result, it has been observed that the wien bridge oscillator circuit with memristor, realized with the Strukov window function, gives a fast and stable output response compared to other window functions. The fact that the center oscillation frequency is very close to the theory has been put forward as another factor that increases the reliability of the system. With this study, which will inspire future analog studies, window functions will be made compatible with electronic cards as 
software, and will occupy a wider place in digital systems where speed is especially important (Staszewski et al., 2005; Ukhina et al., 2019).

\section{References}

Strukov, D. B., Snider, G. S., Stewart, D. R., \& Williams, R. S. (2008). The missing memristor found. nature, 453(7191), 80-83.

Joglekar, Y. N., \& Wolf, S. J. (2009). The elusive memristor: properties of basic electrical circuits. European Journal of physics, 30(4), 661.

Biolek, Z., Biolek, D., \& Biolkova, V. (2009). SPICE Model of Memristor with Nonlinear Dopant Drift. Radioengineering, 18(2).

Prodromakis, T., Peh, B. P., Papavassiliou, C., \& Toumazou, C. (2011). A versatile memristor model with nonlinear dopant kinetics. IEEE transactions on electron devices, 58(9), 3099-3105.

Kvatinsky, S., Friedman, E. G., Kolodny, A., \& Weiser, U. C. (2012). TEAM: Threshold adaptive memristor model. IEEE transactions on circuits and systems I: regular papers, 60(1), 211-221.

Yu, J., Mu, X., Xi, X., \& Wang, S. (2013). A memristor model with piecewise window function. Radioengineering, 22(4), 969-974.

Rak, A., \& Cserey, G. (2010). Macromodeling of the memristor in SPICE. IEEE Transactions on Computer-Aided Design of Integrated Circuits and Systems, 29(4), 632-636.

Chua, L. (1971). Memristor-the missing circuit element. IEEE Transactions on circuit theory, 18(5), 507-519.

Martínez-García, H. (2013). On modified Wien-bridge oscillator and astable oscillator. Analog Integrated Circuits and Signal Processing, 75(1), 179-194.

Namajunas, A., \& Tamasevicius, A. (1995). Modified Wienbridge oscillator for chaos. Electronics letters, 31(5), 335336.

Staszewski, R. B., Hung, C. M., Barton, N., Lee, M. C., \& Leipold, D. (2005). A digitally controlled oscillator in a 90 nm digital CMOS process for mobile phones. IEEE Journal of Solid-State Circuits, 40(11), 2203-2211.

Ukhina, H., Sytnikov, V., Streltsov, O., Stupen, P., \& Yakovlev, D. (2019, September). Specialized computer systems digital bandpass frequency-dependent components rearrangement. In 2019 10th IEEE International Conference on Intelligent Data Acquisition and Advanced Computing Systems: Technology and Applications (IDAACS) (Vol. 1, pp. 168-171). IEEE. 